Abstract OP0085 Table 1 Mean ACR-N and change in TSS at weeks 30,54, and 102 in ACR20 non-responders at week 30

\begin{tabular}{|c|c|c|c|c|c|c|}
\hline & Placebo & $\begin{array}{l}3 \mathrm{mg} / \\
\mathrm{kg} \\
\mathrm{q} 8 \\
\text { wks }\end{array}$ & $\begin{array}{l}3 \mathrm{mg} / \\
\mathrm{kg} \\
\mathrm{q} 4 \\
\text { wks }\end{array}$ & $\begin{array}{l}10 \mathrm{mg} / \\
\mathrm{kg} \\
\mathrm{q} 8 \mathrm{wks}\end{array}$ & $\begin{array}{l}10 \mathrm{mg} / \\
\mathrm{kg} \\
\mathrm{q} 4 \mathrm{wks}\end{array}$ & $\begin{array}{l}\text { Total } \\
\text { infliximab }\end{array}$ \\
\hline Number of ACR 20 & 63 & 39 & 42 & 41 & 32 & 154 \\
\hline ACR-N at Week 30 & 1.2 & 2.3 & 2.9 & $3.5^{*}$ & $3.3^{*}$ & $3.0^{*}$ \\
\hline ACR-N at Week 54 & 2.4 & $9.4^{*}$ & $9.0^{*}$ & $17.1^{*}$ & $17.8^{*}$ & $13.1^{*}$ \\
\hline ACR-N at Week 102 & 3.3 & $12.2^{*}$ & 6.7 & $18.7^{*}$ & $10.1^{*}$ & $11.9^{*}$ \\
\hline $\begin{array}{l}\text { Change in TSS at Week } \\
30\end{array}$ & 5.1 & 2.3 & $0.8^{*}$ & $<0.1^{*}$ & $0.5^{*}$ & $0.9^{*}$ \\
\hline $\begin{array}{l}\text { Change in TSS at Week } \\
54\end{array}$ & 7.2 & $3.0^{*}$ & $1.9^{*}$ & $0.2^{*}$ & $0.3^{*}$ & $1.3^{*}$ \\
\hline $\begin{array}{l}\text { Change in TSS at Week } \\
102\end{array}$ & 13.5 & 3.7 & $1.8^{*}$ & $0.9^{*}$ & $-0.8^{*}$ & $1.4^{*}$ \\
\hline
\end{tabular}

\section{OP0086 THE FULLY HUMAN ANTI-TNF MONOCLONAL ANTIBODY, ADALIMUMAB (D2E7), DOSE RANGING STUDY: THE 24-WEEK CLINICAL RESULTS IN PATIENTS WITH ACTIVE RA ON METHOTREXATE THERAPY (THE ARMADA TRIAL)}

${ }^{1}$ E Keystone, ${ }^{2} \mathrm{ME}$ Weinblatt, ${ }^{3} \mathrm{M}$ Weisman, ${ }^{4} \mathrm{D}$ Furst, ${ }^{3} \mathrm{H}$ Paulus, ${ }^{5} \mathrm{C}$ Birbara, ${ }^{6} \mathrm{~S}$ Fischkoff, ${ }^{6}$ EK Chartash. ${ }^{1} \mathrm{Ctr}$ for Advanced Therapeutics, Mt Sinai Hosp, Toronto, Canada; ${ }^{2}$ Division of Rheumatology, Brigham and Womens Hospital, Boston; ${ }^{3}$ Division of Rheumatology, UCLA, Los Angeles; ${ }^{4}$ Division of Rheumatology, Virginia Mason Clinic, Seattle; ${ }^{5}$ Division of Rheumatology, Univ of Mass, Worcester, ${ }^{6}$ Department of Immunology, Knoll Pharmaceutical Co., Mt. Olive, USA

\subsection{6/annrheumdis-2001.1216}

\section{Background}

Objectives To investigate the clinical efficacy and safety of adalimumab (D2E7), given subcutaneously in combination with methotrexate (MTX) to rheumatoid arthritis (RA) patients who are partial responders to MTX treatment.

Methods The ARMADA Trial was a double-blind placebo controlled study of 271 patients who had active RA despite concurrent stable doses of MTX. The patients were randomised to receive placebo or the fully human anti TNF monoclonal antibody, adalimumab (D2E7), at one of 3 doses (20, 40 and 80 mg every other week). Baseline demographic characteristics included: $76.8 \%$ females, $81 \%$ rheumatoid factor positivity, mean age 55.5 years, mean duration of RA 12.3 years, mean dose of MTX $16.8 \mathrm{mg} /$ week, mean number of previous DMARDs 3.0. These characteristics were well matched between treatment groups.

Results Clinical efficacy results for the placebo controlled 24week period are displayed in the Table 1 below. Adverse events in the adalimumab (D2E7) groups are similar to placebo. Only injection site reactions occurred more frequently with adalimumab (D2E7) in $14.8 \%$ of the patients versus $3.2 \%$ in the placebo group.

\begin{tabular}{lllll}
\multicolumn{6}{l}{ Abstract OP0086 Table 1} \\
\hline & Placebo & $\begin{array}{l}\mathbf{2 0} \mathrm{mg} \\
\text { every other week }\end{array}$ & $\begin{array}{l}\mathbf{4 0} \mathrm{mg} \\
\text { every other week }\end{array}$ & $\begin{array}{l}\mathbf{8 0} \mathbf{~ m g} \\
\text { every other week }\end{array}$ \\
\hline ACR20 & $14.5 \%$ & $49.3 \%^{\mathrm{a}}$ & $65.7 \%^{\mathrm{a}}$ & $65.7 \%^{\mathrm{a}}$ \\
ACR50 & $8.1 \%$ & $31.9 \%^{\mathrm{b}}$ & $53.7 \%^{\mathrm{a}}$ & $52.7 \%^{\mathrm{a}}$
\end{tabular}

\begin{tabular}{lrrr} 
ACR70 $4.8 \% \quad 10.1 \%$ & $26.9 \%^{\mathrm{b}}$ & $19.2 \%^{\mathrm{b}}$ \\
\hline $\mathrm{a}=\mathrm{p}<0.0001, \mathrm{~b}=\mathrm{p}<0.02$.
\end{tabular}

Conclusion The efficacy of the fully human anti-TNF $\alpha$ monoclonal antibody, adalimumab (D2E7), in addition to MTX in patients with longstanding RA is significantly better than placebo when given every other week subcutaneously. The ACR50 and ACR70 responses were impressive in this group of patients with refractory RA.

\section{OP0087 INFLIXIMAB PLUS METHOTREXATE INHIBITS STRUCTURAL DAMAGE, REDUCES SIGN AND SYMPTOMS AND IMPROVES DISABILITY IN PATIENTS WITH ACTIVE EARLY RHEUMATOID ARTHRITIS}

${ }^{1} \mathrm{P}$ Emery, ${ }^{2} \mathrm{R}$ Maini, ${ }^{3} \mathrm{~F}$ Breedveld, ${ }^{4} \mathrm{~J}$ Smolen, ${ }^{5} \mathrm{~J}$ Kalden, ${ }^{6} \mathrm{D}$ Van der Heijde, ${ }^{7} \mathrm{C}$ Han, ${ }^{7} \mathrm{G}$ Harriman. ${ }^{1}$ Rheumatology, University of Leeds, Leeds, UK; ${ }^{2}$ Rheumatology, Kennedy Institute of Rheum, Hammersmith, USA; ${ }^{3}$ Rheumatology, ATTRACT Investigator, Leiden, The Netherlands; ${ }^{4}$ Rheumatology, ATRACT Investigator, Vienna, Austria; ${ }^{5}$ Rheumatology, ATTRACT Investigator, Erlangen; ${ }^{6}$ Rheumatology, ATRACT Investigator, Maastricht, The Netherlands, ${ }^{7}$ Centocor, Inc., Malvern, USA

\subsection{6/annrheumdis-2001.1217}

Background In the ATTRACT trial, 428 pts with active RA despite methotrexate (MTX) therapy received MTX alone or infliximab at $3 \mathrm{mg} / \mathrm{kg}$ or $10 \mathrm{mg} / \mathrm{kg}$ every 4 or 8 weeks along with MTX for 102 weeks. Since joint damage may progress rapidly early in the disease course, pts with early RA (disease duration $<=3$ yrs) were analysed. In this study, 82 of 428 pts (17 placebo, 19 in each of the $3 \mathrm{mg} / \mathrm{kg}$ infliximab group, 20 in the $10 \mathrm{mg} / \mathrm{kg}$ q8 group and 7 in the $10 \mathrm{mg} / \mathrm{kg} \mathrm{q} 4$ group) had early RA.

Objectives To determine prevention of structural damage, reduction in signs and symptoms and improvement in disability in pts with early RA after two years of treatment.

Methods Structural damage was assessed using the Van der Heijde modification of the Sharp score (TSS). Radiographs of hands and feet were obtained at baseline, and after 30, 54 and 102 weeks. Two trained readers scored the films independently. The mean score of the two readers for each set of radiographs was used for further analysis. A clinical response was defined as an ACR 20 response at week 102. Disability was assessed by analysing patients? weighted mean change from baseline HAQ scores through week 102. The changes in TSS and HAQ score from baseline to week 102 were compared between the infliximab treatment groups and the placebo group by using analyses of variance of van der Waerden normal scores. The proportions of pts with a clinical response at week 102 were compared by using chi-square test.

Results The change in TSS from baseline through week 102 was significantly lower in each infliximab dose regiments compared to placebo, as shown in the Table 1 . The clinical response rate was $29 \%$ for the placebo group, $37 \%$ for the $3 \mathrm{mg} / \mathrm{kg}$ q 8 group, $53 \%$ for the $3 \mathrm{mg} / \mathrm{kg} \mathrm{q} 4$ group, $45 \%$ for the $10 \mathrm{mg} / \mathrm{kg}$ q 8 group and $43 \%$ for the $10 \mathrm{mg} / \mathrm{kg} \mathrm{q} 4$. The median improvement in HAQ was 0.2 for the placebo group, 0.2 for the $3 \mathrm{mg} / \mathrm{kg}$ q8 group, 0.5 for the $3 \mathrm{mg} / \mathrm{kg} \mathrm{q} 4$ group, 0.4 for the $10 \mathrm{mg} / \mathrm{kg} \mathrm{q} 8$ group and 0.5 for the $10 \mathrm{mg} / \mathrm{kg} \mathrm{q} 4$. The results for clinical response and HAQ did not reach statistical significance. However, they are consistent with the results of overall study population. 